\title{
Íslenskir stjórnendur: Einkenni, stjórnunaraðferðir og árangur
}

\section{Ingi Rúnar Eðvarðsson, Guðmundur Kristján Óskarsson}

Ágrip: Í pessari grein er varpað ljósi á íslenska stjórnendur, stjórnunaraðferðir peirra og sérkenni. Greinin kannar einnig hvort breytingar hafi orðið á stjórnunaraðferðum á árunum 2004-2007. Rannsóknin byggir á rafrænni spurningalistakönnun par sem stjórnendur í íslenskum fyrirtækjum af ólíkri stærð voru spurðir um stjórnun og svörun var 46\%. Litlar breytingar komu fram milli kannana 2004 og 2007, nema hvað varðar stjórnunarstíl og kyn, liðsstarf og rekstrarárangur. Af öðrum niðurstöðum má nefna að íslenskir stjórnendur beita lýðræðislegum stjórnunaraðferðum og blanda saman ólíkum aðferðum. Konur beita frekar hvetjandi og veitandi stjórnun en karlar velja flestir felandi stjórnun. Meirihluti fyrirtækja er með liðsstarf og pað er algengast í stærri fyrirtækjum á höfuðborgarsvæðinu. Staðsetning fyrirtækja á landinu og starfsgrein fyrirtækja hafði óveruleg áhrif á stjórnun. Stærð fyrirtækja og menntun stjórnenda hafði hins vegar nokkur áhrif á stjórnun. Liðlega sjö af tíu fyrirtækjum voru rekin með hagnaði 2006. Engin sjáanleg tengsl voru á milli stjórnunaraðferða og rekstrarárangurs. Helsta skýring pess er að mikill meirihluti fyrirtækja skilaði hagnaði.

Lykilorð: stjórnunaraðferðir; íslenskir stjórnendur; liðsvinna

\begin{abstract}
This article investigates Icelandic managers, their management methods and characteristics. The article also asks whether there were changes in management methods in Iceland during the years 2004-2007. The study is based on an electronic survey where managers in Icelandic companies of varying size were asked about management. The response rate was $46 \%$. There are few apparent changes between the 2004 and 2007 surveys, except regarding management style and gender and teamwork and company performance. Among other results are that Icelandic managers use democratic management methods and combine differing methods. Women tend to use supporting and coaching techniques while most men choose delegating techniques. The majority of companies have teams and this is most common in larger companies in the Reykjavík area. The geographical location of companies and the industry they are in have a negligible effect on management. The size of the company and the educational level of managers, however, had some effect on management. More than seven of every ten companies operated at a profit during the year 2006. There was no apparent connection between management methods and company performance. The principal explanation for this is that a large percentage of companies turned a profit.
\end{abstract}

Keywords: management; Icelandic managers; teamwork 


\section{Inngangur}

Löngum hefur verið litið til stjórnenda og leiðtoga pegar hugað er að árangri fyrirtækja, stofnana og pjóðríkja. Rannsóknir sýna að farsælir stjórnendur skila betri árangri fyrirtækja, herja, hljómsveita, stjórnmálasamtaka og stéttarfélaga en aðrir stjórnendur og ná auk pess betri árangri í að umbreyta fyrirtækjum og skipulagsheildum (Kreitner, 2004; Buchanan og Huczynski, 2004). Rannsóknir leiða einnig í ljós að stjórnun hefur áhrif á starfsánægju, frammistöðu og framleiðni starfsfólks og starfsmannaveltu (Griffin, 2002; Kreitner, 2004; Mullins, 2005). Af pessu má ráða að rík ástæða sé til að rannsaka stjórnendur fyrirtækja.

Í pessari grein er spurt hvort breytingar hafi orðið á stjórnunaraðferðum í íslenskum fyrirtækjum á síðari árum. Í könnuninni sem framkvæmd var árið 2004 kom fram að flestir stjórnendur beittu lýðræðislegum stjórnunaraðferðum, mikill meirihluti fyrirtækja notaði liðsstarf og stærð fyrirtækja og menntun stjórnenda hafði mikil áhrif á stjórnunaraðferðir sem notaðar voru. Pá skilaði mikill meirihluti fyrirtækja í könnuninni hagnaði. Í pessari grein eru kynntar niðurstöður rannsóknar sem fram fór síðla árs 2007 en hún er framhald sambærilegrar rannsóknar sem framkvæmd var árið 2004 (sjá Ingi Rúnar Eðvarðsson, 2006). Markmið greinarinnar er að varpa ljósi á íslenska stjórnendur, stjórnunaraðferðir peirra og sérkenni, svo sem kyn, búsetu og menntun. Eins og í fyrri rannsókn eru eftirtaldar rannsóknarspurningar settar fram:

- Er munur á stjórnunaraðferðum milli fyrirtækja á landsbyggðinni, Akureyri og nágrenni og höfuðborgarsvæðinu? ${ }^{1}$

- Er munur á stjórnunaraðferðum eftir starfsgreinum og stærð fyrirtækja?

- Er munur á stjórnunaraðferðum háskólamenntaðra stjórnenda og annarra stjórnenda?

- Er rekstrarárangur mismunandi eftir pví hvaða stjórnunaraðferðir stjórnendur beita?

Í öðrum kafla er fjallað um fræðilega umræðu um stjórnun og í peim priðja eru rannsóknaraðferðir kynntar. Gerð er grein fyrir fyrirtækjum og stjórnendum í fjórða kafla og í peim fimmta er fjallað er um stjórnunaraðferðir íslenskra stjórnenda. Rekstrarárangri fyrirtækjanna í könnuninni er lýst í sjötta kafla og helstu niðurstöður eru kynntar í lok greinarinnar.

\section{Fræðileg umræða}

Stjórnun er víðtækt hugtak sem nær yfir marga pætti. Upphaflega lögðu rannsakendur innan leiðtogafræða megináherslu á að rannsaka persónuleikaeinkenni

1 Pessi rannsóknarspurning byggir á peirri forsendu að aðgengi fyrirtækja að menntun og námskeiðshaldi sé ólík eftir pví hvar pau eru staðsett á landinu. Einnig eru hlutfallslega fleiri pjónustufyrirtæki á höfuðborgarsvæðinu og fleiri framleiðslufyrirtæki á landsbyggðinni. Pað getur haft áhrif á val stjórnunaraðferða. 
árangursríkra stjórnenda (e. trait theory). Síðar var lögð áhersla á að pjálfa stjórnendur og auka færni peirra (e. style counseling). Að auki hefur verið bent á mikilvægi aðstæðubundinna pátta í stjórnun (e. contingency theory). Hin síðari ár hefur verið lögð mikil áhersla meðal fræðimanna og ráðgjafa á náðarleiðtoga (e. charismatic leadership) eða umbreytingaleiðtoga (e. transformational leadership), stjórnun liðsheilda (e. team leadership), kynjaða stjórnun (e. gender and leadership) og áhrif menningar á stjórnun (Ása Guðbjörg Guðfinnsdóttir, 2004; Bryman, 1996; Hofstede, 2003; Northhouse, 2007). Fræðimenn hafa jafnframt deilt um pað hvort ein stjórnunaraðferð henti best við allar aðstæður, eins og til dæmis Rensis Likert heldur fram, en hann telur að pátttökustjórnun og lýðræðisleg stjórnun skili bestum árangri óháð aðstæðum (sjá Bryman, 1996). Aðrir fræðimenn aðhyllast pað sjónarmið að stjórnun verði að henta aðstæðum hverju sinni og par má til dæmis nefna Daniel Goleman, Paul Hersey og Kenneth Blanchard (Bryman, 1996; Goleman, 2000).

Í annarri fræðahefð hefur áhersla verið lögð á verkaskiptingu og hlutverk stjórnenda. Pannig lagði F. W. Taylor áherslu á ríka verkaskiptingu, stutta verkferla, aðgreiningu verkundirbúnings og vinnu og peningalega umbun (Taylor, 1997). Henry Fayol fjallaði hins vegar um hlutverk stjórnenda sem hann taldi felast í pví að spá fyrir um framtíðina, skipuleggja og gera áætlanir, gefa fyrirmæli og deila niður verkefnum, samhæfa aðgerðir og hafa eftirlit með starfsemi fyrirtækja (Buchanan og Huczynski, 2004). Á svipaðan hátt telur Henry Mintzberg (1998) að hlutverk stjórnenda felist í mannlegum samskiptum (hann sé táknrænn fulltrúi, leiðtogi og samstarfsaðili); upplýsingahlutverki (hann sé ábyrgðaraðili upplýsinga, miðli peim og sé talsmaður fyrirtækis út á við); og ákvarðanatöku (hann sé frumkvöðull, eigi að halda truflunum í lágmarki, úthluta verðmætum og sé samningamaður). Hér er ekki tóm til að nefna alla pá sem hafa haft áhrif á rannsóknir á stjórnun en geta má Eltons Mayo (1997). Hann taldi rannsóknir sínar leiða í ljós mikilvægi hins óformlega kerfis í skipulagsheildum og mikilvægi vinnuhópa fyrir almenna starfsmenn. Í samræmi við pað lagði hann áherslu á að skapa góðan starfsanda með pví að hlustað sé á umkvartanir starfsfólks. Stjórnendur skulu pjálfaðir í pví að taka tillit til starfsfólks og hinu óformlega kerfi skal ekki útrýmt heldur skal pað sveigt að hinu formlega kerfi.

Hér að neðan er gerð grein fyrir helstu rannsóknum sem gerðar hafa verið um stjórnun í íslenskum fyrirtækjum. Almennum, kenningarlegum rannsóknum, par sem ekki er hugað að fyrrgreindum páttum í fyrirtækjum, er sleppt.

Árelía Eydís Guðmundsdóttir (2002) rannsakaði tengsl á vinnumarkaði og samspil stjórnunarhátta í stofnunum og fyrirtækjum við samskipti aðila vinnumarkaðarins og ytra efnahagsumhverfi á árunum 1987-1995 á Íslandi. Hún ræddi við 41 stjórnanda í stærstu fyrirtækjum á Íslandi, auk pess sem hún studdist við vinnustaðagreiningu Gallups og önnur fyrirliggjandi gögn. Niðurstöður hennar leiða í ljós að ytri breytingar, svo sem efnahagskreppa, mikil óvissa og alpjóðavæðing, höfðu mikil áhrif á íslenska stjórnendur. Langtímastefnumótun, leiðtogahæfni og áætlanagerð urðu mun mikilvægari en áður og pað jók mjög pýðingu fagstjórnenda. Sami 
höfundur (2005) kannaði einnig áhrif viðhorfa hjá 20 millistjórndum í einu 200 manna hátæknifyrirtæki á árangur peirra í starfi. Árelía Eydís leggur vonarkenningu til grundvallar og kemst að pví að vongóðir stjórnendur séu líklegri til að ná meiri árangri við markmiðssetningu verkefna hjá starfsmönum sínum en peir sem eru vonlitlir. Sama rannsókn og kenningarammi var notaður til að kanna samræmingu á milli vinnu og einkalífs hjá millistjórnendum. Niðurstöður eru pær að millistjórnendum, sem hafa mikinn viljastyrk, eru útsjónarsamir og vongóðir, gengur betur en öðrum að samræma vinnu og einkalíf (Inga Hanna Guðmundsdóttir og Árelía Guðmundsdóttir, 2005).

Harpa Björg Guðfinnsdóttir og Inga Jóna Jónsdóttir (2005) hafa fjallað um próun stjórnendahæfi í litlum og meðalstórum fyrirtækjum. Pær byggja niðurstöður sínar á rannsókn Hörpu Bjargar en hún tók viðtöl við 10 stjórnendur í fyrirtækjum með 2-100 starfsmenn. Helstu niðurstöður eru pær að stór hluti af starfi viðmælendanna fer í að sinna starfsmanna- og sölumálum. Viðmælendur töldu einnig að félagsleg hæfni skipti mestu í starfi sínu. Við próun hæfni er páttur óformlegra leiða mikill og athygli vekur að frumkvöðlar sækja ekki formlegar námsleiðir.

Ása Guðbjörg Ásgeirsdóttir (2004) hefur rannsakað áhrif stjórnunarstíls og trú stjórnenda á eigin stjórnunarfærni á viðhorf undirmanna til starfs síns og sálfélagslegs vinnuumhverfis. Hún lagði spurningalista fyrir á níu vinnustöðum (fimm pjónustufyrirtækjum og fjórum stofnunum). Alls svöruðu 472 einstaklingar, par af 76 yfirmenn og 396 undirmenn peirra. Heildarsvörun var 69\%. Ása Guðbjörg leitaðist við að sýna fram á að undirmenn umbreytingarstjórnenda (e. transformational leadership) séu jákvæðari gagnvart starfi sínu og vinnuumhverfi en undirmenn stjórnenda sem beita öðrum stjórnunarstíl. Niðurstöður hennar staðfesta pað. Undirmenn umbreytingastjórnenda voru ánægðari í starfi og fengu meiri hvatningu og stuðning frá yfirmönnum sínum. Loks töldu peir að betur væri hugað að mannauði og að par ríkti menning og starfsandi sem hvetti fólk til nýbreytni. Rannsóknin studdi hins vegar ekki pá tilgátu að undirmenn aðgerðastjórnenda (e. transactional leadership) væru neikvæðari til starfs síns og sálfélagslegs vinnuumhverfis, að pví undanskildu að peir upplifðu meira andlegt álag í starfi en undirmenn umbreytingastjórnenda. Af öðrum niðurstöðum má nefna að trú á stjórnunarfærni hafði lítið forspárgildi um viðhorf undirmanna og að yfirmenn mátu sig að jafnaði með meiri umbreytingarstjórnunarstíl en undirmenn peirra gerðu. Pá töldu undirmenn að kvenkyns stjórnendur sýndu fleiri einkenni umbreytingarstjórnunarstíls en karlkyns stjórnendur.

Tveir einstaklingar hafa rannsakað stjórnun í íslenskum útrásarfyrirtækjum. Annars vegar fjallar G. Dögg Gunnarsdóttir (2007) um íslenskan stjórnunarstíl í útrásarfyrirtækjum. Hún tók viðtöl við stjórnendur í premur fyrirtækjum og kemst að peirri niðurstöðu að stjórnendurnir séu yngri en gerist erlendis, séu umbreytingarleiðtogar, séu starfsmönnum góðar fyrirmyndir og veiti peim umboð til athafa. Peir vinna jafnframt eftir láréttu skipulagi, ákvarðanataka peirra er hröð og stéttleysi ríkir innan fyrirtækjanna. Helga Harðardóttir (2007) rannsakaði ákvarðanatöku í útrásar- 
fyrirtækjum með viðtölum við stjórnendur og með pví að leggja fyrir spurningalista í tveimur fyrirtækjum. Niðurstöður benda til að hraði í ákvarðanatöku og frumkvöðlahneigð sé mikil í útrásarfyrirtækjum, sem og vertíðarmenning.

Tvær nýlegar rannsóknir hafa verið gerðar á íslenskum kvenstjórnendum. Árelía Eydís Guðmundsdóttir (2008) tók viðtöl við átta kvenkyns forstjóra og framkvæmdastjóra og kemst að peirri niðurstöðu að pær hafa haft meira fyrir leiðtogahlutverkinu en karlar, að gerð sé krafa um að pær séu mjúkar en purfi jafnframt að sanna að pær geti tekið ákvarðanir og verið „harðar“. Flestar hafa valið að verða „ein af strákunum“ og látið fordóma í sinn garð ekki trufla sig í að ná settu marki. Margrét Sæmundsdóttir (2009) gerði athugun á pví hvort íslensk fyrirtæki sem hafa bæði kynin í stjórn séu líklegri til pess að skila meiri arðsemi en fyrirtæki sem eru með einsleitar stjórnir og hvort munur væri á stjórnunaraðferðum kynjanna. Gerð var athugun á 101 fyrirtæki í pessu samhengi og jákvætt marktækt samband fannst milli pess að hafa bæði kynin í stjórn fyrirtækisins og arðsemi eigin fjár og veikt en jákvætt samband við arðsemi heildareigna. Hins vegar komu engin tengsl fram pegar skoðað var hvort seta kvenna í stjórnum leiddi til fleiri kvenna í stjórnendastöðum og betri stjórnunarhá með tilliti til starfsmanna. Kvenstjórnendur deildu síður verkefnum til undirmanna sinna en karlar og pær töldu sig frekar verða fyrir hindrunum í starfi.

Ingi Rúnar Eðvarðsson (2004; 2005) hefur rannsakað útbreiðslu og árangur pekkingarstjórnunar í íslenskum fyrirtækjum. Par kemur fram að tiltölulega fá fyrirtæki hafa tekið upp aðferðir pekkingarstjórnunar, fá fyrirtæki hafa mótað stefnu um miðlun og nýtingu pekkingar og fyrirtækin hafa ekki fjárfest í hápróuðum pekkingarstjórnunarkerfum. Árangur pekkingarstjórnunar virðist vera mikill hjá peim fyrirtækjum sem hafa innleitt hana. Hann hefur einnig rannsakað stjórnunaraðferðir og skipulag íslenskra fyrirtækja (Ingi Rúnar Eðvarðsson, 2006). Ingi Rúnar og Víði Vernharðsson (2008) gerðu rannsókn á ákvarðanatöku í fjórum fyrirtækjum og byggðist hún á viðtölum við stjórnendur og greiningu gagna úr fyrirtækjunum. Flestir stjórnendanna reiddu sig mikið á eigið innsæi og reynslu við smærri ákvarðanir en pó einnig í sumum tilfellum við pær stærri. Hjá öllum fyrirtækjunum var í einhverjum tilfellum stuðst við Stjórnunarvísindi í grunninn og pegar kom endanlega að pví að taka stóra ákvörðun var pað gert af tveimur eða fleiri einstaklingum samkvæmt Carnegie-líkaninu. Meginniðurstaða rannsóknarinnar var sú að hvorki tegund starfsemi né skipulagsform fyrirtækjanna höfðu áhrif á ákvarðanatökuferlið en greinilegur munur var á ferlinu ef tekið var mið af stærð peirra.

Af framansögðu má ráða að margar rannsóknir hafa verið gerðar á liðnum árum hér á landi um stjórnunaraðferðir, einkanlega í stærri fyrirtækjum. Heildstæða vitneskju um stjórnunaraðferðir í íslenskum fyrirtækjum hefur skort. Рað á einkanlega við um stöðu mála í minni og miðlungsstórum fyrirtækjum. Af pessum sökum var ákveðið að ráðast á ný í pá könnun sem kynnt er í pessari grein. 


\section{Rannsóknaraðferðir}

Sú rannsóknaraðferð sem best hentar markmiðum rannsóknarinnar er lýsandi rannsóknaraðferð (e. descriptive research) sem miðast við að finna tíðni, hlutföll og tengsl breyta og að staðfesta eða hafna tilgátum. Tvær algengustu gerðir kannana eru spurningalistakannanir og viðtalskannanir (oftast í gegnum síma). Helstu kostir viðtalskannana er að tiltölulega auðvelt er að ná til fólks og pað tryggir mikla svörun; aðferðin er skjótvirk; mögulegt er að koma í veg fyrir að spurningar séu misskildar og auðvelt er að fylgjast með gangi könnunarinnar. Kostir spurningalistakannana eru hins vegar peir að pær eru tiltölulega einföld leið til gagnaöflunar; ekki parf að ná til fólks á tilteknum tíma; engar skekkjur verða vegna áhrifa spyrla og svarendur hafa betra næði til að svara. Helsti ókostur peirra er lágt svarhlutfall (Churchill, 2002).

Spurningalistakönnun var valin í rannsókninni. Helsta ástæðan var að pannig yrði auðveldara að ná til stjórnenda en að taka símaviðtal við pá. Einnig hafði pað áhrif á val rannsóknaraðferðar að áhugi var á pví að endurtaka fyrri könnun frá árinu 2004 sem var netkönnun (sjá Ingi Rúnar Eðvarðsson, 2006). Í báðum tilvikum var stuðst við netkönnun og sömu spurningar voru notaðar í báðum könnunum að pví undanskildu að árið 2007 var sett inn ný spurning varðandi náðarleiðtogaeinkenni. Slík aðferð býður upp á ódýra og einfalda leið til að afla gagna og felur í sér kosti spurningalistakannana. Helstu ókostir slíkra aðferða eru að úrtakslistar eru ekki aðgengilegir og pví er erfitt að velja fyrirtæki, pær krefjast aðgangs að neti og tæknileg vandamál geta komið upp á við framkvæmd könnunarinnar (Malhrota og Birks, 2003).

Könnunin hófst 21. nóvember 2007 og henni lauk 18. desember sama ár. Rannsóknarstofnun Háskólans á Akureyri sá um framkvæmd hennar. Sendur var spurningalisti í viðhengi með tölvupósti til forstöðumanna fyrirtækja og stofnana eða staðgengla peirra. Outcome-forritið var notað til að halda utan um gögnin og taka saman frumniðurstöður en gögnin voru unnin frekar í SPSS-forriti. Ítrekun um pátttöku og spurningalisti var sendur fjórum sinnum til fólksins í úrtakinu til að auka svörun. Ekki var heitið neinum verðlaunum fyrir pátttöku.

Sú ákvörðun að senda spurningalista með tölvupósti getur falið í sér hættu á skekkju, sem felst í pví að ungir, vel menntaðir stjórnendur í stærri fyrirtækjum svari frekar en aðrir stjórnendur. Svo reyndist ekki vera hvað stærð fyrirtækja varðar par sem $60 \%$ stjórnenda í könnuninni stýrðu fyrirtækjum með færri en 20 starfsmönnum. Af peim stjórnendum sem svöruðu höfðu 57,8\% lokið háskólanámi og meðalaldur peirra var 46,2 ár. Par sem upplýsingar liggja ekki fyrir um menntun og aldur íslenskra stjórnenda er erfitt að meta svörun út frá peim forsendum.

Pýði kom frá Ríkisskattstjóra sem var pversnið af íslenskum fyrirtækjum með fimm starfsmenn eða fleiri launpega árið 2006 og hafa skilað inn launamiðum fyrir átta milljónir eða meira. ${ }^{2}$ Fyrirtæki voru valin pannig að helmingur kæmu af höfuð-

2 Val á stærð fyrirtækja í úrtaki miðaðist við að fá pversnið af íslenskum fyrirtækjum en ekki einungis peim stærstu eins og flestar rannsóknir á fyrirtækjum hér á landi hafa einblínt á. Neðri 
borgarsvæðinu, 25\% af Eyjafjarðarsvæðinu og afgangurinn annars staðar af landinu. Rökin fyrir pví voru pau að pannig væri hægt að bera saman fyrirtæki miðað við staðsetningu peirra á landinu. Upprunalegur pýðislisti innihélt 5031 fyrirtæki og stofnanir. Aðstandendur rannsóknarinnar ákváðu af röklegum ástæðum að fella brott fyrirtæki í landbúnaði (búrekstur), ${ }^{3}$ landbúnaðarráðunauta, dvalarheimili aldraðra og heimili fyrir fatlaða, starfsemi stjórnmálaflokka og kirkjur og trúfélög. Ástæðan var sú að í slíkum rekstri reyndi mjög lítið á stjórnun og skipulag par sem um fáa starfsmenn eða mikið um sjálfboðavinnu er vanalega að ræða. Eftir stóðu pá 4846 fyrirtæki og stofnanir á pýðislistanum. Úrtakið var valið pannig að 890 fyrirtæki og stofnanir voru valin með fyrrgreinda landfræðilega skiptingu í huga. Síðan voru leituð uppi netföng á heimasíðum eða á já.is. Pannig fengust upplýsingar um 537 netföng sem var endanlegt úrtak. Landfræðileg dreifing fyrirtækja á netfangalistanum endurspeglaði mjög vel upprunalegt pýði.

Svör bárust frá 222 fyrirtækjum, tvö voru hætt rekstri og óvirk netföng voru 54. Рað pýðir að svörun var 46,1\%. Takmörkuð svörun er vel pekkt vandamál í spurningalistakönnunum. Aaker, Kumar og Kay rita t.d. (2001, bls. 226): „Á pví leikur enginn vafi að vandinn við lágt svarhlutfall einkennir spurningalistakannanir. Ef spurningalisti er eintaldlega sendur til venjulegs slembiúrtaks, án viðeigandi áminninga, er líklegt að svörun verði innan við 20\%." Vandinn er oftar meiri í fyrirtækjakönnunum par sem tímaskortur og álag dregur úr svörun. Netkannanir juku svarhlutfall í fyrstu upp í 50-60\% en pað hefur síðan lækkað niður í 25-30\% pegar nýjungabragurinn hefur horfið með aukinni notkun slíkra kannana (Burns og Bush, 2003). Í pví ljósi er 46\% svörun góð og endurspeglar hún mjög vel pýðið.

Er dreifing peirra sem ekki svöruðu eins og peirra sem svöruðu? Eins og fram kemur síðar í pessri grei hafa pátttakendur í könnuninni eftirtalin sérkenni í samanburði við tölur frá Hagstofu Íslands um íslensk fyrirtæki almennt árið 2006: Peir stýra fyrirtækjum með fleiri en 20 starfsmenn í meira mæli en almennt gerist (frávik 35,9 prósentustig); fleiri koma úr einkahlutafélögum en öðrum rekstrarformum (frávik 32,3 prósentustig), og tiltölulega færri stýra fyrirtækjum í pjónustu en meðaltal segir til um (frávik 18,4 prósentustig). Niðurstöður verður að túlka með pað í huga.

Spurningalistinn innihélt 44 spurningar. Hann var að mestu smíð peirra sem stóðu að rannsókninni en stuðst var við aðra spurningalista um stjórnunaraðferðir (líkan Herseys og Blanchards, 1988), pekkingarstjórnun (sjá KPMG Consulting, 2000; Lim og Ahed, 2000) og árangursmælingar (sjá Nilsson og Kald, 2002). Spurningalistinn var forprófaður í nokkrum fyrirtækjum og lagfærður lítillega í kjölfar pess. Spurningalistanum var skipt upp í bakgrunnsupplýsingar, skipulag og stjórnun, mannauðsstjórnun, pjónustustjórnun, gæðastjórnun, pekkingarstjórnun og stefnumótun. Fjöldi svarmöguleika í hverri spurningu var frá einum (t.d. að skrá aldur

mörk voru dregin við fimm starfsmenn par sem lítið sem ekkert reynir á skipulega stjórnun eða skipulag í fyrirtækjum með færri starfsmenn.

3 Kjötvinnsla og sláturhús eru í úrtaki og flokkast til iðnaðar. 
sinn), premur (já/nei/veit ekki) upp í 14 svarmöguleika (t.d. hvaða ávinning fyrirtæki hafi af pekkingarstjórnum). Í nokkrum spurningum var heimilt að merkja við fleiri en eitt svar. Í flestum spurningunum var stuðst við nafna- eða röðunarskala sem aðeins heimila að reikna út fjölda, tíðni og að nota krosstöflur. Spurningar um skipulag byggðu flestar á fjögurra flokka Likert-skala. Í spurningum um aldur, starfsaldur, fjölda starfsmanna og veltu var stuðst við millibils- og hlutfallslega skala par sem flóknari tölfræði er möguleg. Við tölfræðilega úrvinnslu var algengast að reikna út fjölda og tíðni en krosstöflur voru oftast gerðar um tengsl stjórnunar við stærð og pá starfsgrein sem viðkomandi fyrirtæki starfar í, auk menntunar stjórnenda. P-gildi og kí-kvaðrat var jafnframt reiknað út. Til að skera úr um marktækni milli hópa (t.d. fyrirtæki á höfuðborgarsvæðinu og landsbyggðinni) var stuðst við tveggja hlutfalla próf. ${ }^{4}$

Hér verður aðeins gerð grein fyrir peim hluta spurningalistans sem fjallar um stjórnendur og stjórnunaraðferðir.

\section{Fyrirtæki og stjórnendur}

Eins og fyrr segir bárust svör frá 222 fyrirtækjum. Liðlega helmingur peirra (53,5\%) er staðsettur á höfuðborgarsvæðinu, 22,3\% eru á Akureyri og nágrenni og önnur fyrirtæki dreifðust um landið. Раð endurspeglar úrtakið vel sem var valið með landfræðilega dreifingu í huga, p.e. að um helmingur væri staðsettur á höfuðborgarsvæðinu og að 25\% væru frá Akureyri og nágrenni pannig að mögulegt væri að greina fyrirtæki par sérstaklega. Helsta skekkjan í könnuninni er að hlutfallslega fleiri stjórnendur á höfuðborgarsvæðinu svara henni en stjórnendur annars staðar á landinu, einkanlega á Akureyri og nágrenni.

Fyrirtækin sem tóku pátt í könnuninni höfðu 59 starfsmenn að meðaltali á launaskrá árið 2006. ${ }^{5}$ Um 44\% fyrirtækjanna hafði 10 starfsmenn eða færri, 60\% fyrirtækjanna var með 20 starfsmenn eða færri og 92\% peirra hafði 100 starfsmenn eða færri. Eins og áður hefur komið fram eru fyrirtækin í könnuninni nokkru stærri en skrá yfir stærð íslenskra fyrirtækja hjá Hagstofu Íslands gefur til kynna (Hagstofa Íslands, 2008a). Um helmingur fyrirtækjanna í pessari könnun hafði 1-5 háskólamenntaða starfsmenn en 24,5\% fyrirtækja hafði engan háskólamenntaðan starfsmann. Hlutfall háskólamenntaðra starfsmanna er 25,68\% að meðaltali.

Velta fyrirtækjanna árið 2006 var 706 milljónir að meðaltali (frá 1,6 milljónum upp í 18 milljarða); 25\% fyrirtækjanna höfðu 62 milljónir í veltu eða minna, 50\%

4 Formúlan er: $\quad z=\frac{p_{1}-p_{2}}{\sqrt{\frac{p_{1}\left(100-p_{1}\right)}{n_{1}}+\frac{p_{2}\left(100-p_{2}\right)}{n_{2}}}}$

5 Eitt fyrirtæki skar sig úr og var með 4600 starfsmenn. Pegar pað er tekið út úr útreikningum lækkar meðaltalið í 37,6 starfsmenn. 
fyrirtækja höfðu 132 milljónir eða minni veltu og um 19\% höfðu veltu sem var meiri en 700 milljónir.

Karlstjórnendur voru 79,5\% svarenda og 20,5\% konur. Pað er nokkru fleiri kvenstjórnendur en meðal 100 stærstu fyrirtækja á Íslandi 2007 (14\%) en nokkru minna en meðal Evrópulanda par sem gögn frá Eurostat sýna að konur voru 32\% stjórnenda árið 2004. Athygli vekur að hlutfall kvenstjórnenda er undir meðallagi á Norðurlöndum (Holst, 2006; Rannsóknarsetur vinnuréttar og jafnréttismála, 2007).

Af peim stjórnendum sem svöruðu könnuninni höfðu 57,9\% lokið háskólanámi, 37,0\% höfðu framhaldsskóla- og iðnmenntun og 5,1\% svarenda höfðu eingöngu lokið grunnskólanámi. Meðalaldur svarenda var 46,2 ár (sá yngsti 24 ára og sá elsti 68 ára). Meðalstarfsaldur í núverandi fyrirtæki var 9,8 ár.

Algengasta rekstrarform fyrirtækja í könnuninni voru einkahlutafélög (ehf.) en 67,9\% fyrirtækjanna voru skráð með peim hætti. Pví næst komu almenningshlutafélög eða 13,7\% fyrirtækja í könnuninni, 5,6\% svarfyrirtækja voru fyrirtæki ríkis eða sveitarfélaga og annars konar rekstrarformi tilheyrðu samtals 12,8\% fyrirtækjanna. Ef mið er tekið af flokkun Hagstofunnar á fyrirtækjum eftir rekstrarformi er ljóst að svörin eru skekkt par sem hlutfallslega flest fyrirtæki sem svöruðu könnuninni eru hlutafélög. Í skrá Hagstofunnar voru hlutafélög (almennings- og einkahlutafélög) 49,5\% og félagasamtök og sjálfseignarstofnanir fylgja par fast á eftir með 37,4\% hlutdeild (Hagstofa Íslands, 2008b).

Loks er pess að geta að um 4,7\% fyrirtækja í könnuninni störfuðu í frumvinnslu (landbúnaði eða sjávarútvegi) ${ }^{6}$, 27,9\% í iðnaði og úrvinnslu, 60\% í pjónustu af ýmsu tagi og 7,4\% fyrirtækja voru í öðrum ótilgreindum rekstri. Ef skipting fyrirtækja á atvinnugreinar er borin saman við skiptingu Hagstofunnar á fjölda fyrirtækja og félaga eftir atvinnugreinum 2006 kemur í ljós að frumvinnslufyrirtæki voru 4,4\% fyrirtækja og félaga, iðnfyrirtæki 12,8\% og pjónustufyrirtæki 78,5\% af heildarfjölda (Hagstofa Íslands, 2008c). Pjónustufyrirtæki hafa pví minni svörun en aðrar atvinnugreinar miðað við heildarpýði.

Á pessu stigi liggja fyrir sérkenni fyrirtækjanna og peirra stjórnenda sem svöruðu könnuninni og pví er ekki úr vegi að kynna pær niðurstöður sem snúa að stjórnunaraðferðum fyrirtækja.

\subsection{Stjórnunaraðferðir: Almenn stjórnun}

Ekki er auðvelt að spyrjast fyrir um stjórnunaraðferðir par sem um flókið fyrirbæri er að ræða. Í okkar tilviki jók pað einnig á vandann að spurningalistinn var langur og rými til að fjalla um stjórnunaraðferðir sérstaklega var takmarkað. Til að nálgast viðfangsefnið með spurningalistaaðferð var stuðst við líkan Herseys og Blanchards (1988) um aðstæðubundna stjórnun (e. situational leadership). Ástæða pess er að pað er vel pekkt og mikið notað við pjálfun stjórnenda: og hafa 400 fyrirtæki á lista Fortune-

6 Vert er að minna á að landbúnaðarfyrirtæki voru felld úr úrtaki eins og fram hefur komið. 
tímaritsins yfir 500 helstu fyrirtæki notað líkanið í stjórnendapjálfun. Líkanið leggur auk pess áherslu á sveigjanleika í stjórnunaraðferðum og er auðvelt í framkvæmd. Líkan Herseys og Blanchards hefur verið gagnrýnt fyrir að pað styðjist að litlu leyti við rannsóknir og að ekki sé tekið mið af mikilvægum páttum eins og kyni og aldri pátttakenda (Northhouse, 2007).

Hersey og Blanchard telja að stjórnandi verði að velja stjórnunaraðferð sem henti aðstæðum hverju sinni, p.e. áhuga og hæfni starfsmanns til að leysa verkefni. Peir aðgreina fjórar stjórnunaraðferðir en pær eru stýrandi (e. directive), hvetjandi (e. supportive), veitandi (e. coaching) og felandi (e. delegating) stjórnun (sjá töflu 1).

Tafla 1. Hugmyndir Pauls Herseys og Kenneths Blanchards um aðstæðubundna stjórnun.

\begin{tabular}{|c|c|}
\hline $\begin{array}{l}\text { Stýrandi } \\
\text { Lítill verkefnaproski og áhugi starfsmanns. } \\
\text { Stjórnandi gefur nákvæm fyrirmæli og } \\
\text { fylgist grannt með frammistöðu } \\
\text { starfsmanna. }\end{array}$ & $\begin{array}{l}\text { Hvetjandi } \\
\text { Lítill eða miðlungsmikill verkefnaproski, } \\
\text { mikill áhugi starfsmanns. } \\
\text { Stjórnandi veitir upplýsingar, útskýrir, spyr } \\
\text { og hvetur til dáða. }\end{array}$ \\
\hline $\begin{array}{l}\text { Veitandi } \\
\text { Miðlungsmikill eða mikill verkefnaproski, } \\
\text { e.t.v. lítill vilji starfsmanns. } \\
\text { Stjórnandi veitir uppörvun, stuðning og } \\
\text { hvatningu, hvetur til pátttöku. }\end{array}$ & $\begin{array}{l}\text { Felandi } \\
\text { Mikill verkefnaproski, mikill áhugi } \\
\text { starfsmanns. } \\
\text { Stjórnandi færir starfsmanni vald til að vinna } \\
\text { á eigin forsendum, fylgist með álengdar. }\end{array}$ \\
\hline
\end{tabular}

Pegar stjórnendur voru spurðir um hvaða stjórnunaraðferðum peir beiti svöruðu 80 (37\%) að peir útskýri verkefni, láti starfsfólk vinna á eigin forsendum og fylgist með álengdar (felandi stjórnun). ${ }^{7}$ Nokkru færri $(28,2 \%)$ veita starfsfólki upplýsingar, útskýra ákvarðanir og spyrja og hvetja (hvetjandi stjórnun). Meðal stjórnenda blanda $24 \%$ saman ólíkum stjórnunaraðferðum (sjá mynd 1). Athygli vekur að innan við 3\% stjórnenda beita stjórnunarferðum í anda einvaldsstjórnunar, p.e. að segja starfsfólki nákvæmlega fyrir verkum og fylgjast vel með pví (stýrandi stjórnun). Nokkrar breytingar eru milli kannana. Pannig segjast fleiri stjórnendur styðjast við felandi og veitandi stjórnun 2007 en 2004 og færri segjast blanda saman stjórnunaraðferðum eða nota hvetjandi stjórnun. Breytingarnar nema um 3-4 prósentustigum og eru ekki marktækar. Ekki er munur á vali stjórnenda á stjórnunaraðferðum eftir pví í hvaða starfsgrein peir starfa.

7 Við spurningu um hvaða stjórnunaraðferðum stjórnendur beiti voru gefnir sex valmöguleikar. Hver stjórnunaraðferð var útskýrð nánar í orðum, t.d. „segi starfsfólki nákvæmlega hvernig og hvenær pað eigi að vinna störfin og fylgist vel með starfsfólki.“ Pað er dæmi um stýrandi stjórnun. Auk fjögurra stjórnunaraðferða Hersey og Blanchard var gefinn kostur á að merkja við pá möguleika að blanda saman aðferðum og ekkert af ofantöldu. 


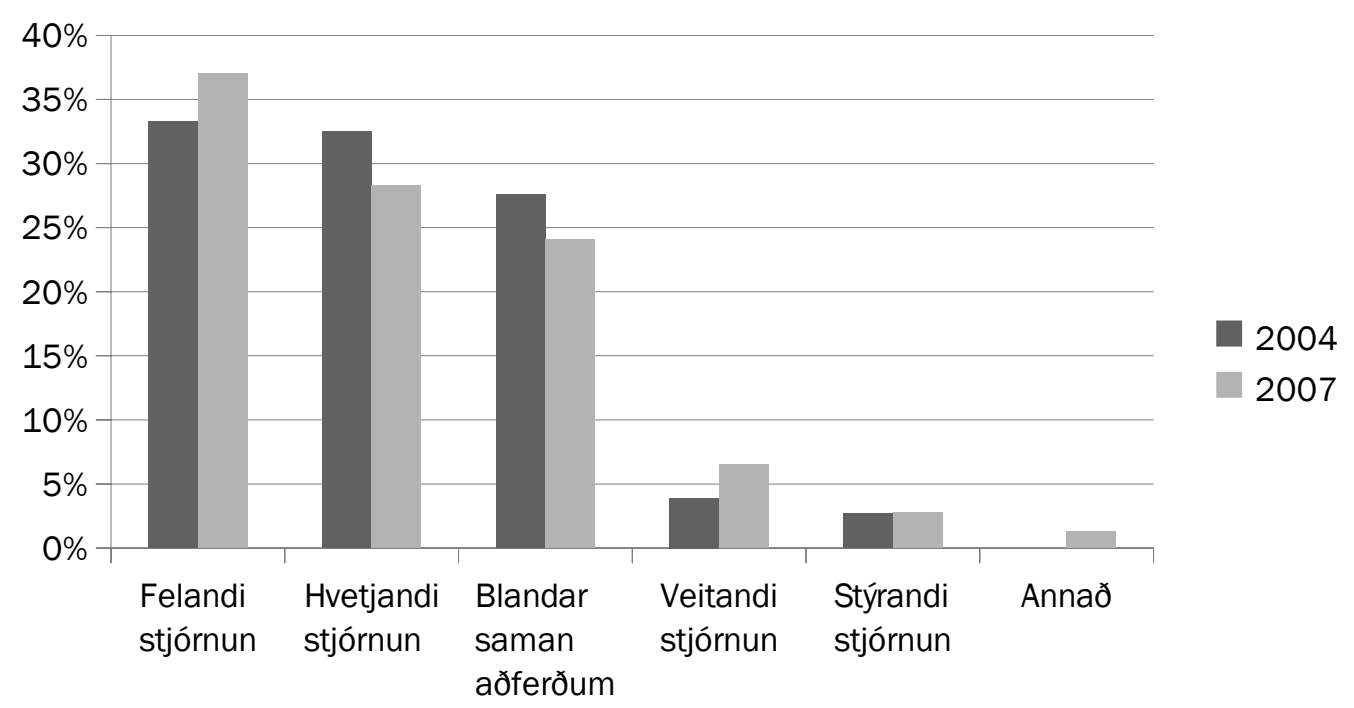

Mynd 1. Hvaða stjórnunaraðferðum beitir pú í starfi pínu sem stjórnandi, 2004 og 2007. n= 262 (2004), 216 (2007).

Menntun stjórnenda virðist hafa áhrif á val stjórnunaraðferða. Stjórnendur sem lokið hafa grunnskólanámi beita helst felandi og blönduðum stjórnunaraðferðum, iðn- og framhaldsskólamenntaðir stjórnendur nota mest felandi og hvetjandi stjórnun en háskólamenntaðir stjórnendur velja hvetjandi, blandaðar og felandi stjórnunaraðferðir nær jöfnum höndum (sjá töflu 2). Munurinn á milli grunnskóla-, iðn-, framhaldsskóla- og háskólamenntaðra stjórnenda er marktækur pegar stuðst er við Kí-kvaðrat próf $(\mathrm{p}=0,019)$.

Tafla 2. Menntun stjórnenda og stjórnunaraðferðir.

\begin{tabular}{lllll}
\hline & Grunnskólanám & Framhaldsskólanám & Iðnnám & Háskólanám \\
\hline Stýrandi & $0,00 \%$ & $3,30 \%$ & $8,50 \%$ & $0,80 \%$ \\
Hvetjandi & $18,20 \%$ & $26,70 \%$ & $19,10 \%$ & $32,80 \%$ \\
Veitandi & $0,00 \%$ & $6,70 \%$ & $4,30 \%$ & $6,40 \%$ \\
Felandi & $45,40 \%$ & $50,00 \%$ & $53,20 \%$ & $28,00 \%$ \\
Blandar saman & $36,40 \%$ & $10,00 \%$ & $12,80 \%$ & $31,20 \%$ \\
Annað & $0,00 \%$ & $3,30 \%$ & $2,10 \%$ & $0,80 \%$ \\
& $100,00 \%$ & $100,00 \%$ & $100,00 \%$ & $100,00 \%$ \\
Fjöldi & 11 & 30 & 47 & 125 \\
\hline
\end{tabular}

Kí $=28,36, d f=15, p=0,019$

Kvenstjórnendur velja helst hvetjandi stjórnun (35\%) en karlarnir velja flestir felandi stjórnun (41\%) eins og fram kemur í töflu 3.. Einnig nota konur frekar veitandi stjórnun heldur en karlar. Karlar eru peir einu sem beita stýrandi stjórnun en aðeins var um 6 einstaklinga að ræða. Kynjamunurinn er marktækur pegar stuðst er 
við Kí-kvaðrat próf ( $p=0,031)$. Enginn kynjamunur var merkjanlegur í könnuninni 2004.

Tafla 3. Kyn stjórnenda og stjórnunaraðferðir.

\begin{tabular}{lll}
\hline & Karl & Kona \\
\hline Stýrandi & $3,5 \%$ & $0,0 \%$ \\
Hvetjandi & $26,5 \%$ & $34,8 \%$ \\
Veitandi & $3,5 \%$ & $14,0 \%$ \\
Felandi & $41,2 \%$ & $23,3 \%$ \\
Blandar saman & $24,1 \%$ & $25,6 \%$ \\
Annað & $1,2 \%$ & $2,3 \%$ \\
& $100,0 \%$ & $100,0 \%$ \\
\hline Fjöldi & 170 & 43 \\
\hline
\end{tabular}

$\mathrm{K}_{1}^{\prime}=12,28, \mathrm{df}=5, \mathrm{p}=0,031$

Fyrirtæki á höfuðborgarsvæðinu virðast síður velja felandi og veitandi stjórnun en fyrirtæki annars staðar á landinu. Pessi munur er pó ekki marktækur. Stærð fyrirtækja hefur engin sýnileg áhrif á pær stjórnunaraðferðir sem valdar eru.

Samkvæmt kenningum um náðarleiðtoga (e. charismatic leadership) hegða slíkir leiðtogar sér með einstökum hætti sem hefur mikil áhrif á fylgjendur peirra. Talið er að peir hafi fimm sérkenni sem aðgreini pá frá öðrum leiðtogum. Pessi sérkenni eru pau að peir hafi mjög mótaða sýn á framtíðina; peir eru tilbúnir að taka áhættu til að ná fram peirri sýn; næmni hvað varðar umhverfi og parfir undirmanna sinna; peir sýna hegðun sem er óhefðbundin. Rannsóknir sýna jafnframt að náðarleiðtogar hvetja undirmenn sína til dáða pannig að peir afreka meira og eru ánægðari í starfi en undirmenn hefðbundinna leiðtoga. Skýringa er að leita í pví undirmenn eru betur meðvitaðir um mikilvægi sértækra og háleitra markmiða; peir taka hagsmuni skipulagsheildar framyfir eigin hagsmuni og peir fást við skapandi og háleit markmið. Pá skapa náðarleiðtogar traust meðal starfsfólks (Robbins, 2003; Northhouse, 2007).

Pátttakendur í rannsókninni voru beðnir að taka afstöðu til eftirtalinna fullyrðinga: Ég hef mjög skýra framtíðarsýn og á auðvelt með að miðla henni til annarra; Ég er reiðubúinn að taka mikla áhættu til að hrinda sýn minni í framkvæmd; Ég skynja vel parfir og væntingar annarra og bregst skjótt við peim; Ég framkvæmi hluti með nýstárlegum hætti og framkoma mín er óhefðbundin. Svarendur gátu merkt við mjög sammála, frekar sammála, frekar ósammála og mjög ósammála. Svör pátttakenda gefur að líta á mynd 2. Par kemur fram að liðlega 90\% svarenda er mjög eða frekar sammála fullyrðingunum um að peir hafi skýra framtíðarsýn og að peir skynji vel parfir og væntingar annarra. Mun færri voru sammála hinum tveimur fullyrðingunum. Pannig voru aðeins um helmingur svarenda mjög eða frekar sammála pví að peir væru reiðubúnir að taka mikla áhættu til að hrinda sýn í framkvæmd og 
nokkru færri sögðust framkvæma hluti með nýstárlegum hætti. Aðeins 60 stjórnendur merktu mjög sammála við allar fjórar fullyrðingarnar og geta pannig talist hafa náðarleiðtogaeinkenni.

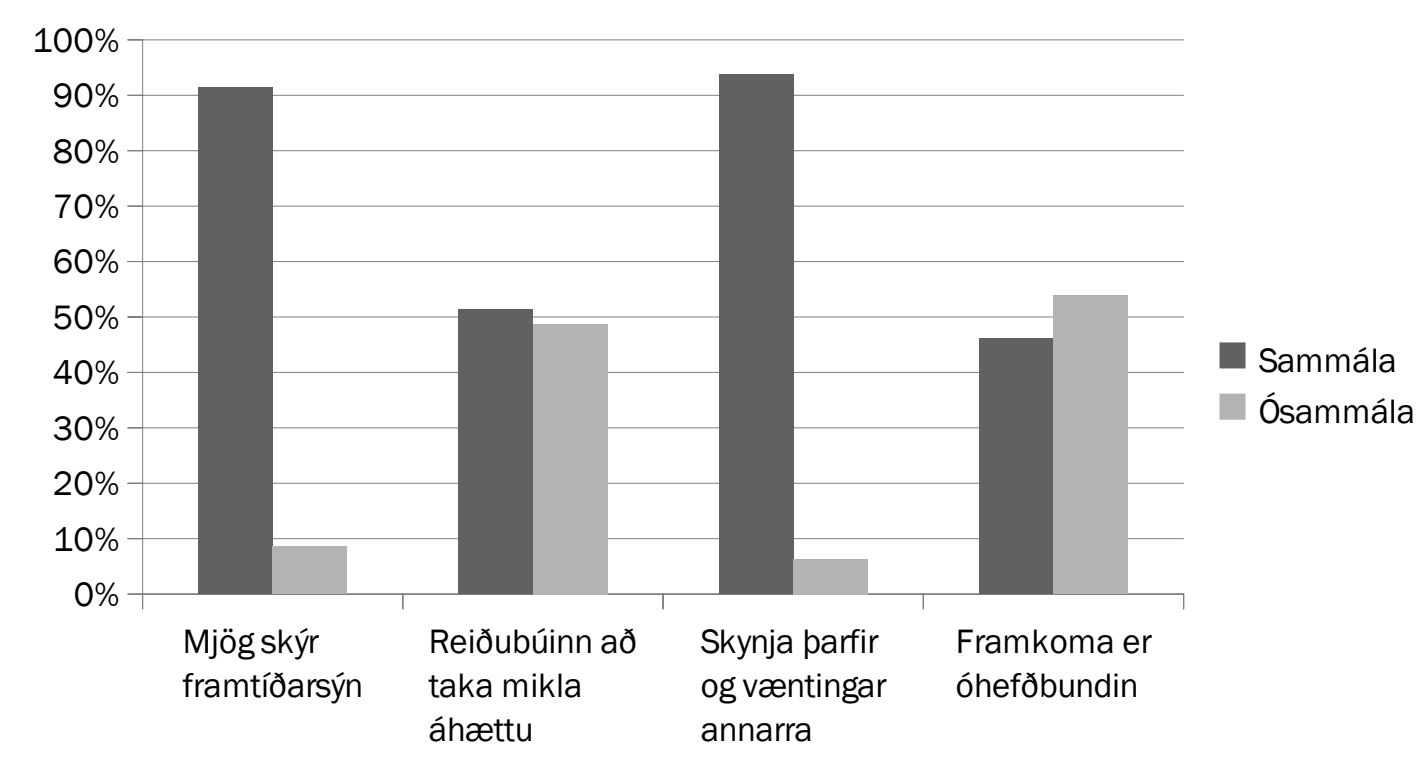

Mynd 2. Svör pátttakenda við fullyrđingum um náðarleiðtogaeinkenni.

Enginn munur var á körlum og konum hvað varðar fyrrgreindar fullyrðingar. Lítill munur var einnig á menntun stjórnenda og hvort peir telja sig til náðarleiðtoga og pað hafði ekki áhrif á rekstrarárangur. Рað á einnig við um starfsgrein sem stjórnendur starfa í sem og stærð fyrirtækja.

\subsection{Stjórnunaraðferðir: Liðsvinna}

Rannsóknir hafa leitt í ljós að liðsvinna getur aukið framleiðni, lækkað framleiðslukostnað og örvað nýsköpun. Enn fremur má nefna að hún er talin geta aukið ánægju viðskiptavina, starfsánægju, hollustu við fyrirtæki og gæði vöru og pjónustu (Zárraga og Bonance, 2003; Buchanan og Huczynski, 2004). Aukin alpjóðleg samkeppni og örar tæknibreytingar hafa pví ýtt undir vinsældir liðsvinnu innan stjórnunarfræðanna. Ein spurning í könnuninni laut að pví að spyrja um liðs- eða hópastarf í fyrirtækjum. Alls bárust 216 svör við peirri spurningu og stjórnendur í 145 fyrirtækjum $(67,1 \%)$ sögðu að liðs- eða hópastarf væri við lýði í fyrirtækinu. Pað er nokkru minna en árið 2004 en pá sögðu 71,5\% stjórnenda að liðsstarf væri í fyrirtækinu. Liðsstarf var algengast í iðnaði (71,7\%), pá í frumvinnslufyrirtækjum (70,0\%) og loks í pjónustufyrirtækjum (65,6\%). Munurinn er ekki tölfræðilega marktækur.

Fyrirtæki á höfuðborgarsvæðinu nota liðsstarf mest en 76,3\% svöruðu að pau nýti sér hópastarf, 58,0\% fyrirtækja á landsbyggðinni og 58,3\% fyrirtækja á Akureyri og nágrenni (sjá töflu 4). Kí-kvaðrat-stuðull í töflu 3 (p=0,017) gefur til kynna að um 
samband sé að ræða milli liðsstarfs og staðsetningar fyrirtækja. Munurinn er tölfræðilega marktækur pegar borin eru saman hlutföll hópa milli höfuðborgarinnar og landsbyggðarinnar $(\mathrm{p}=0,018)$ og höfuðborgarinnar og Akureyrar $(0,027)$. Munurinn er hins vegar ekki marktækur milli landsbyggðarinnar og Akureyrar. Árið 2003 voru pað fyrirtæki á landsbyggðinni sem notuðu liðsstarf mest (sjá Ingi Rúnar Eðvarðsson, 2006).

Tafla 4. Liðsstarf og staðsetning fyrirtækja.

\begin{tabular}{llll}
\hline & Höfuðborgin & Akureyri & Landsbyggðin \\
\hline Liðstarf & $76,3 \%$ & $58,3 \%$ & $57,7 \%$ \\
Ekki liðstarf & $23,7 \%$ & $41,7 \%$ & $42,3 \%$ \\
& $100,0 \%$ & $100,0 \%$ & $100,0 \%$ \\
\hline Fjöldi & 114 & 48 & 52 \\
\hline
\end{tabular}

$\mathrm{Kí}=8,185, \mathrm{df}=2, \mathrm{p}=0,017$

Fyrirtæki með fleiri en 50 starfsmenn nota liðsstarf í 83,3\% tilfella en minni fyrirtæki í $64,4 \%$ tilfella. Kí-kvaðrat-stuðull $(4,9, p=0,027)$ hafnar núll-tilgátunni og munurinn er tölfræðilega marktækur pegar borin eru saman hlutföll tveggja hópa $(p=0,008)$.

Liðsvinna virðist leiða til betri rekstrarafkomu fyrirtækja pví að marktækur munur er á pví hvort fyrirtæki sem hafa tekið upp liðsstarf séu rekin með hagnaði eða tapi ( $p=0,024)$. Petta eru aðrar niðurstöður en í könnuninni 2003 pví að pá var enginn marktækur munur.

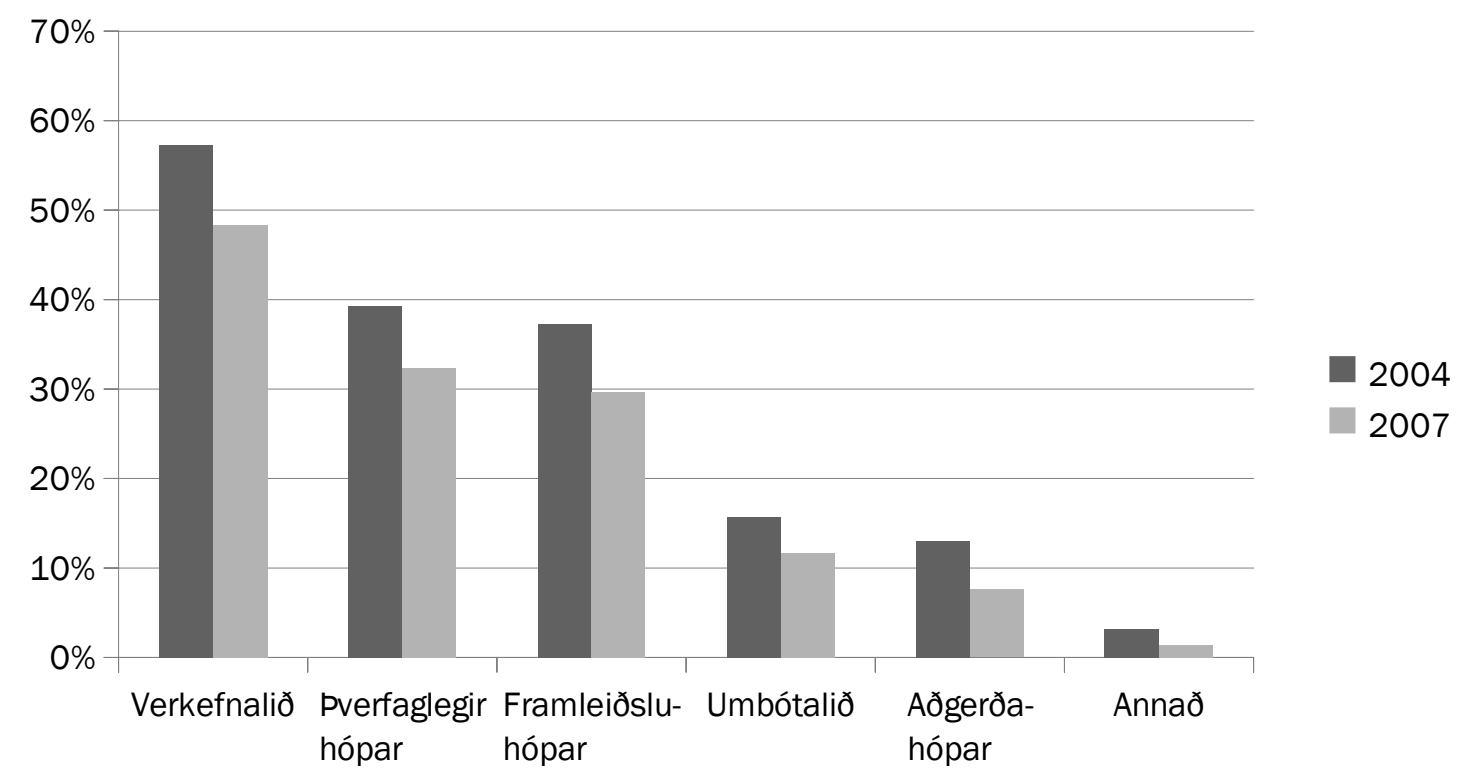

Mynd 3. Hvernig hópar eru við lýđi í fyrirtækinu? Merkt við fleiri en eitt svar ef við á. 
Við spurningu um pað hvers konar hópastarf sé í fyrirtækjum bárust svör frá 138 fyrirtækjum og par sem mögulegt var að merkja við fleiri en eitt svar bárust alls 190 svör. Verkefnalið (að vinna í teymi að tilteknu verkefni) eru algengasta form hópastarfs og er pað að finna í 50,7\% fyrirtækja. Pverfaglegir hópar, par sem fólk úr mismunandi deildum vinnur saman, eru einnig algengir en slíkir hópar eru við lýði í 34,0\% fyrirtækja og síðan koma framleiðsluhópar sem vinna að staðaldri saman í framleiðslu eða pjónustu (31,2\%). Umbótalið er að finna í um 12,3\% fyrirtækja og aðgerðahópa í 8\% fyrirtækja (sjá mynd 3). •að er mjög ápekk dreifing og árið 2004.

Af pví sem fram kemur hér að ofan er ljóst að liðsvinna er algeng í íslenskum fyrirtækjum. •að á einkum við um stærri fyrirtæki á höfuðborgarsvæðinu.

\section{Rekstrarárangur}

Stjórnunaraðferðir eru mikilvægar fyrir rekstur og afkomu fyrirtækja eins og fyrr segir. Stjórnun hefur áhrif á starfsánægju, frammistöðu og framleiðni starfsfólks, liðsvinnu, starfsmannaveltu og rekstrarárangur fyrirtækja (Griffin, 2002; Buchanan og Huzcynski, 2004; Kreitner, 2004; Mullins, 2005).

Athyglisvert er að kanna hvort stjórnunaraðferðir hafi áhrif á rekstrarárangur fyrirtækjanna í könnuninni. Í könnuninni var rekstrarárangur einungis metinn út frá pví hvort fyrirtækin skiluðu hagnaði eða ekki. Meirihluti fyrirtækja er svöruðu könnuninni, eða 155 (74,2\%), var rekinn með hagnaði árið 2006, 34 (16,3\%) voru rekin með tapi og 19 (9,1\%) á núlli (sjá mynd 4). Hlutfall fyrirtækja sem rekin voru með tapi var prem prósentustigum hærra en árið á undan. Séu pessar niðurstöður yfirfærðar á pýðið er ekki hægt að fullyrða að breyting hafi átt sér stað milli ára.

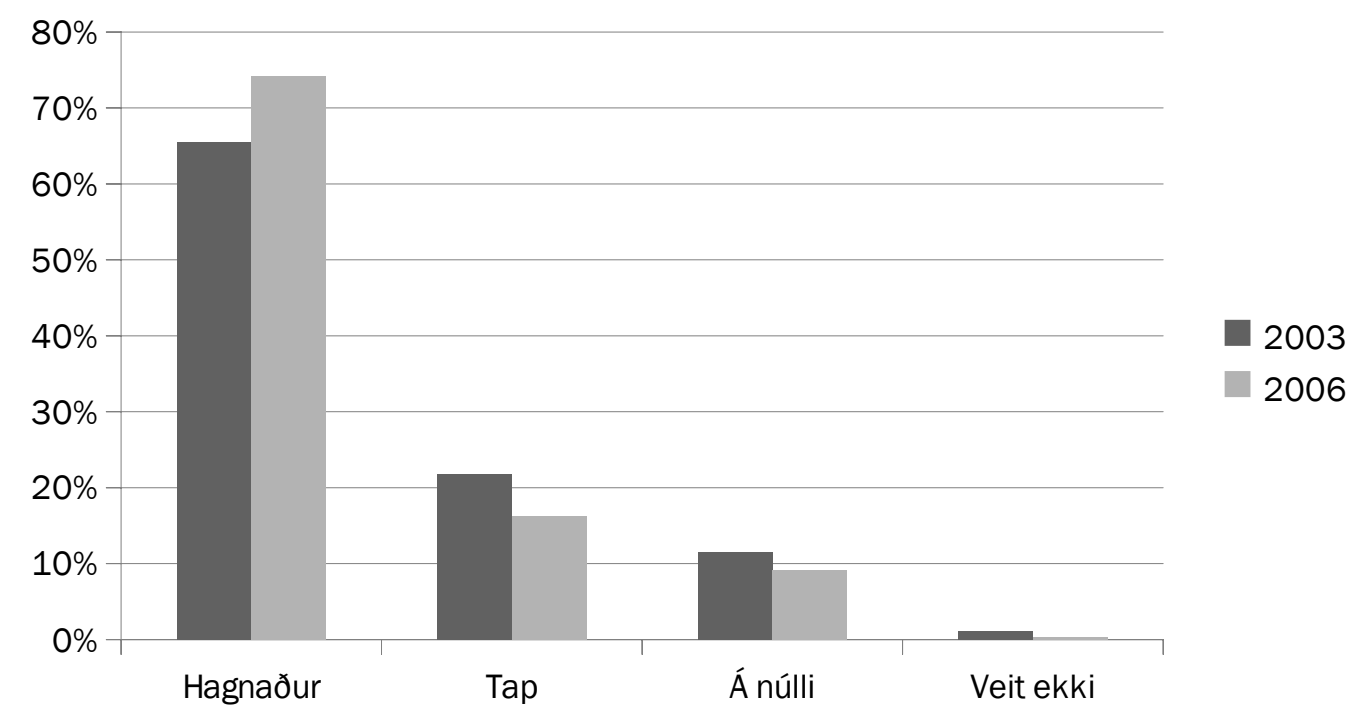

Mynd 4. Rekstrarafkoma fyrirtækja í könnuninni 2003 og 2006. 
Stærð fyrirtækja virðist ekki hafa áhrif á afkomu peirra og ekki heldur landfræðileg staðsetning. Afkoma fyrirtækja er hins vegar ólík eftir starfsgreinum. Besta afkoman er í iðnaði og frumvinnslugreinum en nokkru slakari í pjónustufyrirtækjum. Munurinn á iðnfyrirtækjum og pjónustufyrirtækjum er marktækur pegar hlutföll tveggja hópa eru borin saman $(p=0,028)$ en pað á ekki við um mun á milli frumvinnslu- og iðnfyrirtækja eða frumvinnslu- og pjónustufyrirtækja. Stjórnunaraðferðir hafa ekki áhrif á rekstrarárangur fyrirtækjanna í könnuninni. Menntun stjórnenda virðist hins vegar hafa áhrif á árangur fyrirtækjanna. Athyglisvert er að hlutfallslega skila stjórnendur með iðnnám bestum árangri en grunnskólamenntaðir stjórnendur slökustum árangri. Kí-kvaðrat-stuðull í töflu 5 (p=0,004) gefur til kynna að sambandið sé ekki háð tilviljun. Munurinn á milli rekstrarárangurs iðnmenntaðra stjórnenda og stjórnenda með aðra menntun er marktækur miðað við tveggja hlutfalla próf $(p=0,004)$. Hins vegar ber að varast að draga of víðtækar ályktanir af pví par sem líklegt er að aðrir stjórnendur séu í fyrirtækjunum sem hafi aðra menntun og auk pess eru tæplega 20\% fyrirtækja í könnuninni fyrirtæki sem ekki stefna að hagnaði. Pá eru margir aðrir pættir sem hafa áhrif á rekstrarárangur, svo sem skattamál, hráefnisverð, samkeppnisstaða o.fl.

Tafla 5. Menntun stjórnenda og rekstrarárangur.

\begin{tabular}{lllll}
\hline & Grunnskólanám & Framhaldsskólanám & Iðnnám & Háskólanám \\
\hline Hagnaður & $44,4 \%$ & $75,9 \%$ & $93,2 \%$ & $82,2 \%$ \\
Tap & $55,6 \%$ & $24,1 \%$ & $6,8 \%$ & $17,8 \%$ \\
& $100,0 \%$ & $100,0 \%$ & $100,0 \%$ & $100,0 \%$ \\
\hline Fjöldi & 9 & 29 & 44 & 107 \\
\hline
\end{tabular}

$\mathrm{Ki}^{\prime}=13,078, \mathrm{df}=3, \mathrm{p}=0,004$

Af pví sem fram kemur hér að framan er ljóst að stjórnunaraðferðir virðast ekki hafa áhrif á rekstrarárangur fyrirtækjanna sem svöruðu könnuninni. Рað er mjög athyglisvert og petta atriði parf frekari rannsókna við.

\section{Niðurstöður}

Stjórnendur í könnuninni beita felandi stjórnun í 37\% tilvika, nokkuð færri eða 28,2\% styðjast við hvetjandi stjórnun og 24,1\% blanda saman ólíkum stjórnunaraðferðum. Konur beita aðallega hvetjandi stjórnun en karlar felandi stjórnun.

Alls kváðust 145 fyrirtæki $(67,1 \%)$ vera með liðs- eða hópastarf í starfsemi sinni. Fyrirtæki á höfuðborgarsvæðinu nota liðsstarf mest, pá fyrirtæki á Akureyri og nágrenni og loks á landsbyggðinni. Fyrirtæki með fleiri en 50 starfsmenn nota liðsvinnu oftar en fyrirtæki með færri starfsmenn. Verkefnalið er að finna í 50,7\% fyrirtækjanna, pverfaglega hópa í 34,0\% peirra og framleiðsluhópa í 31,2\% peirra og aðgerðahópa í 8\% peirra. 
Meirihluti fyrirtækjanna sem svaraði könnuninni (74,2\%) var rekinn með hagnaði árið 2006. Iðnfyrirtæki skiluðu oftar hagnaði en pjónustufyrirtæki. Iðnmenntaðir stjórnendur skiluðu oftar hagnaði en stjórnendur með aðra menntun en túlka ber pær niðurstöður með varúð par sem margir pættir hafa áhrif á hagnað fyrirtækja. Stjórnunaraðferðir virðast ekki hafa áhrif á rekstrarárangur.

Hér verða helstu niðurstöður dregnar saman í samræmi við rannsóknarspurningar:

- Staðsetning fyrirtækja á landinu hafði aðeins áhrif á notkun liðsvinnu.

- Starfsgrein stjórnanda hafði ekki marktæk áhrif á stjórnunaraðferðir en rekstrarafkoma er betri í iðn- og frumvinnslufyrirtækjum en pjónustufyrirtækjum.

- Stærri fyrirtæki nota liðsvinnu oftar en minni fyrirtæki.

- Háskólamenntaðir stjórnendur virðast beita öðrum stjórnunaraðferðum en stjórnendur með aðra menntun. Peir taka engan stjórnunarstíl fram yfir annan ef einvaldsstjórnun er undanskilin. Iðnmenntaðir stjórnendur skila hins vegar hlutfallslega bestum rekstrarárangri.

- Engin sjáanleg tengsl voru á milli stjórnunaraðferða og rekstrarárangurs. Helsta skýring pess er að mikill meirihluti fyrirtækja skilaði hagnaði árið 2006.

\subsection{Mikilvægi fyrir stjórnendur}

Niðurstöður rannsóknarinnar gætu gagnast stjórnendum á Íslandi með ýmsu móti og má til dæmis nefna eftirfarandi atriði:

- Pær gefa til kynna sérkenni, árangur og stjórnunaraðferðir íslenskra stjórnenda í samanburði við erlenda stjórnendur sem mikið hefur verið tekið mið af í innlendu viðskiptanámi til pessa.

- Pær gefa til kynna próun meðal stjórnenda á síðari árum.

- Menntun og reynsla kvenna virðist vera vannýtt auðlind í íslenskum fyrirtækjum par sem aðeins 20,5\% stjórnenda eru konur borið saman við 32\% í Evrópulöndum.

- Taka parf mið af menntun stjórnenda. Svo virðist sem iðnmenntun og háskólamenntun hafi áhrif á marga pætti stjórnunar og skili fyrirtækjum betri rekstrarárangri en ella. Forráðamenn fyrirtækja purfa pví að gefa menntun stjórnenda meiri gaum í framtíðinni.

\subsection{Fræðilegt framlag og frekari rannsóknir}

Niðurstöður könnunarinnar eru um margt áhugaverðar par sem heildstæða vitneskju hefur skort á pessu sviði á Íslandi. Könnunin er framhald sambærilegrar könnunar frá árinu 2004. Slík endurtekning eflir mjög pekkingu á íslenskum stjórnendum og starfsháttum peirra. Niðurstöður kannananna eru um margt mjög sambærilegar (sjá Ingi Rúnar Eðvarðsson, 2006). Рað bendir til pess að könnunin frá árinu 2004 hafi gefið pversnið af starfsháttum íslenskra stjórnenda. Par sem tímabilið 2004- 
2007 einkenndist af penslu og góðri afkomu fyrirtækja er ólíklegt að ætla að knýjandi pörf hafi verið á pví að endurskoða stjórnunaraðferðir í fyrirtækjum.

Íslenskir stjórnendur velja helst felandi stjórnun og hvetjandi stjórnun, auk pess að blanda saman aðferðum. Erlendis takast fræðimenn á um pað hvort ein stjórnunaraðferð henti best við allar aðstæður, t.d. lýðræðisleg stjórnun (sjá Bryman, 1996) en aðrir aðhyllast pað sjónarmið að stjórnun verði að henta aðstæðum hverju sinni (Goleman, 2000; Bryman, 1996). Stjórnunaraðferðir íslenskra stjórnenda gefa til kynna að peir hallist að síðara sjónarmiðinu og peir blanda gjarnan saman aðferðum.

Niðurstöður varðandi menntun stjórnenda, sérstaklega sú að iðnskólamenntun skuli vera hlutfallslega hagnýtust, eru í samræmi við rannsóknir í anda mannauðsumræðunnar (Schultz, 1961; Becker, 1992). Par kemur fram að fjárfesting í framhaldsskólamenntun skilar bæði einstaklingum og pjóðfélagi hvað mestum ávinningi.

Frekari rannsókna er pörf á stjórnunaraðferðum íslenskra fyrirtækja. Pannig væri áhugavert að kafa dýpra ofan í einstaka pætti rannsóknarinnar með viðtölum og vinnustaðagreiningu og fá álit fleiri en stjórnenda einna. Einnig væri áhugavert að gera tilraun á tengslum stjórnunaraðferða og rekstrarárangurs. Pannig pyrfti að kanna tengsl milli stjórnunar og starfsmannaveltu, framleiðni, nýsköpunar, ánægju viðskiptavina o.fl. pátta sem gætu skýrt rekstrarárangur fyrirtækja og stofnana. Pá væri fróðlegt að kanna hvort efnahagskreppan sem nú herjar á efnahagslífið hafi leitt til pess að stjórnendur séu t.d. strangari en áður og geti frekar beitt einvaldsstjórnun en fyrir kreppu.

\subsection{Takmarkanir rannsóknar}

Allar rannsóknir eru takmörkunum háðar. Í pessari rannsókn má segja að lágt svarhlutfall dragi úr peirri vissu sem hægt er að álykta með út frá niðurstöðum. Til málsbóta má pó telja að úrtakið var lagskipt og endurspeglar pannig nokkuð vel heildarpýði. Með pví að bera pau fyrirtæki sem svöruðu könnuninni saman við upplýsingar um einkenni íslenskra fyrirtækja frá Hagstofu Íslands virðast helstu skekkjur vera pær að peir sem pátt tóku í könnuninni stýrðu stærri einkahlutafélögum í frumvinnslu og iðnaði en meðaltal íslenskra fyrirtækja gefur til kynna. Pá má nefna að niðurstöður byggja aðallega á nafnabreytum og pað kallar á varfærni við að yfirfæra niðurstöður almennt yfir á íslensk fyrirtæki.

\section{Lokaord}

Í pessari grein var fjallað um rannsókn á íslenskum stjórnendum og stjórnunaraðferðum peirra sem er framhald sambærilegrar rannsóknar frá árinu 2004. Markmið greinarinnar var að varpa ljósi á íslenska stjórnendur, stjórnunaraðferðir peirra og sérkenni. Meðal rannsóknarspurninga eru til dæmis pær hvort hvort munur sé á stjórnunaraðferðum milli fyrirtækja á höfuðborgarsvæðinu og landsbyggðinni, eftir 
starfsgreinum og hvort rekstrarárangur sé ólíkur eftir pví hvaða stjórnunaraðferðum stjórnendur beiti.

Niðurstöður benda til að íslenskir stjórnendur notist við lýðræðislegar stjórnunaraðferðir (felandi stjórnun) eða blandi saman ólíkum aðferðum. Konur beita öðrum stjórnunaraðferðum en karlar. Meirihluti fyrirtækja er með liðsstarf og pað er algengast í stærri fyrirtækjum á höfuðborgarsvæðinu. Liðlega sjö af tíu fyrirtækjum voru rekin með hagnaði 2006. Litlar breytingar komu fram milli kannana 2004 og 2007, nema hvað varðar stjórnunarstíl og kyn, liðsstarf og rekstrarárangur.

Í ljós kom að staðsetning fyrirtækja á landinu og starfsgrein fyrirtækja hafi óveruleg áhrif á stjórnun. Stærð fyrirtækja og menntun stjórnenda hafði hins vegar nokkur áhrif á stjórnun. Engin sjáanleg tengsl voru á milli stjórnunaraðferða og rekstrarárangurs. Helsta skýring pess er að mikill meirihluti fyrirtækja skilaði hagnaði árið 2006. Pörf er á frekari rannsóknum á stjórnunaraðferðum og skipulagi til að efla íslenskt atvinnulíf og tryggja varanlegan árangur fyrirtækja.

\section{Um höfundana}

Ingi Rúnar Eðvarðsson er prófessor í stjórnun við viðskiptadeild Háskólans á Akureyri. Netfang: ire@unak.is. Guðmundur Kristján Óskarsson er lektor við sömu deild. Rannsóknin var styrkt af Rannsóknasjóði Háskólans á Akureyri og Háskólasjóði KEA. Höfundar vilja pakka tveimur nafnlausum ritrýnum fyrir góðar ábendingar við vinnslu greinarinnar.

\section{Heimildir}

Aaker, D. A., Kumar, V. og Day, G. S. (2001). Marketing research. 7. útgáfa. New York: John Wiley \& Sons.

Árelía Eydís Guðmundsdóttir (2002). Íslenskur vinnumarkaður á umbrotatímum. Sveigjanleiki skipulagsheilda, stjórnun og endurskipulagning efnahagslifsins. Reykjavík: Háskólinn í Reykjavík.

Árelía Eydís Guðmundsdóttir (2005). Hefur viðhorf millistjórnenda áhrif á árangur peirra í starfi? Í Ingjaldur Hannibalsson (ritstj.) Rannsóknir í félagsvísindum VI. Erindi flutt á rádstefnu í október 2005. Reykjavík: Félagsvísindadeild Háskóla Íslands og Háskólaútgáfan.

Árelía Eydís Guðmundsdóttir (2008). Ein af strákunum: Íslenskir kvenstjórnendur. Í Ingjaldur Hannibalsson (ritstj.) Rannsóknir í félagsvísindum IX. Erindi flutt á rádstefnu í október 2008. Reykjavík: Félagsvísindadeild Háskóla Íslands.

Ása Guðbjörg Ásgeirsdóttir (2004). Stjórnunarstíll, trú stjórnenda á eigin stjórnunarfærni og viðhorf undirmanna til starfs sins og vinnuumhverfis. M.S. ritgerð við viðskipta- og hagfræðideild Háskóla Íslands.

Becker, G. S. (1992). Human capital and the economy. Proceedings of the American Philosophical Society, $136(1), 85-92$.

Bryman, A. (1996). Leadership in organizations. Í Clegg, S. W., Hardy, C. og Nord, W. R. (ritstj.), Handbook of organization studies. London: Sage Publications. 
Buchanan, D. og Huczynski, A. (2004). Organizational behaviour. 5. útgáfa. London: Prentice Hall.

Burns, A. C. og Bush, R. F. (2003). Marketing research: online research applications. Upper Saddle River, N.J.: Prentice Hall.

Churchill, G. A. (2002). Marketing research: methodological foundations. Fort Worth: Harcourt College Publishers.

G. Dögg Gunnarsdóttir (2007). „,...við erum alltof ungir til pess að leggja árar í bát.” Um íslenskan stjórnunarstíl í útrásarfyrirtækjum. Í Ingjaldur Hannibalsson (ritstj.) Rannsóknir í félagsvísindum VIII. Erindi flutt á ráđstefnu í desember 2007. Reykjavík: Félagsvísindadeild Háskóla Íslands.

Griffin, R. W. (2002). Management. 7. útgáfa. Boston: Houghton Mifflin.

Goleman, D. (2000). Leadership that gets results. Harvard Business Review, 78 (2), 78-90.

Hagstofa Íslands (2008a). Fjöldi launagreiðenda eftir starfsmannafjölda, landsvæðum og atvinnugreinum 1998-2005. Sótt 19. mars 2008 af http://www.hagstofa.is.

Hagstofa Íslands (2008b). Fjöldi skráðra fyrirtækja og félaga eftir rekstrarformi 1999-2006. Sótt 19. mars 2008 af http://www.hagstofa.is/uploads/files/LH07/L070401.xls.

Hagstofa Íslands (2008c). Fjöldi fyrirtækja og félög eftir atvinnugreinum 1996-2006. Sótt 19. mars 2008 af http://www.hagstofa.is/uploads/files/LH07/L070404.xls.

Harpa Björg Guðfinnsdóttir og Inga Jóna Jónsdóttir (2005). Próun stjórnendahæfni í litlum og meðalstórum fyrirtækjum. Í Ingjaldur Hannibalsson (ritstj.) Rannsóknir í félagsvísindum VI. Erindi flutt á rádstefnu í október 2005. Reykjavík: Félagsvísindadeild Háskóla Íslands og Háskólaútgáfan.

Helga Harðardóttir (2007). Hröð ákvarðanataka í íslenskum útrásarfyrirtækjum. M.S. ritgerð við viðskipta- og hagfræðideild Háskóla Íslands.

Hersey, P. og Blanchard, K. H. (1988). Management of organizational behavior: utilizing human resources. Englewood Cliffs, N.J.: Prentice Hall.

Hofstede, G. (2003). Cultures and organizations: intercultural cooperation and its importance for survival. London: Profile Books.

Holst, E. (2006). Women and managerial positions in Europe: focus on Germany. Management Revue, 17 (2), 122-142.

Inga Hanna Guðmundsdóttir og Árelía Eydís Guðmundsdóttir (2005). Vongóðir millistjórnendur og samræming vinnu og einkalífs. Í Ingjaldur Hannibalsson (ritstj.) Rannsóknir í félagsvísindum VI. Erindi flutt á rádstefnu í október 2005. Reykjavík: Félagsvísindadeild Háskóla Íslands og Háskólaútgáfan.

Ingi Rúnar Eðvarðsson (2004). Dekkingarstjórnun. Akureyri: Háskólinn á Akureyri.

Ingi Rúnar Eðvarðsson (2005). Er pekkingarstjórnun viðhafnarinnar virði? Niðurstöður alpjóðlegra kannana. Í Ingjaldur Hannibalsson (ritstj.) Rannsóknir i félagsvísindum VI. Erindi flutt á rádstefnu í október 2005. Reykjavík: Félagsvísindadeild Háskóla Íslands og Háskólaútgáfan.

Ingi Rúnar Eðvarðsson (2006). Stjórnunaraðferðir og skipulag íslenskra fyrirtækja. Tímarit um viðskipti og efnahagsmál, útgáfa 2006, 3-26.

Ingi Rúnar Eðvarðsson og Víðir Vernharðsson (2008). Ákvarðanataka í íslenskum fyrirtækjum. Í Ingjaldur Hannibalsson (ritstj.) Rannsóknir i félagsvísindum IX. Erindi flutt á ráđstefnu i október 2008. Reykjavík: Félagsvísindadeild Háskóla Íslands. 
KPMG Consulting (2000). Knowledge management research report 2000. Annapolis/London: Höfundur.

Kreitner, R. (2004). Management. 9. útgáfa. Boston: Houghton Mifflin.

Lim, K. K. og Ahmed, P. K. (2000). Enabling knowledge management: a measurement perspective. Í Proceedings of the 2000 IEEE international conference on management of innovation and technology, 2, 690-695.

Malhrota, N. K. og Birks, D. F. (2003). Marketing research: an applied approach. Harlow: Prentice Hall.

Margrét Sæmundsdóttir (2009). Konur og stjórnunarhættir fyrirtækja á Íslandi. Bifröst Journal of Social Science, 3.

Mayo, E. (1997). Hawthorne and the Western Electric Company. Í Pugh, D. S. (ritstj.) Organization theory: selected readings. London: Penguin Books.

Mintzberg, H. (1998). The manager's job: folklore and fact. Bls. 1-36 í Harvard Business Review on Leadership. Boston: Harvard Business School Press.

Mullins, L. J. (2005). Management and organisational behaviour. 7. útgáfa. Harlow: Prentice Hall.

Nilsson, F. og Kald, M. (2002). Recent advances in performance management: the Nordic case. European Management Journal, 20 (3), 235-245.

Northhouse, P. G. (2007). Leadership: theory and practice. Thousand Oaks: SAGE Publications.

Rannsóknarsetur vinnuréttar og jafnréttismála (2007). Jafnréttiskennitalan: Birting upplýsinga um janfrétti i 100 stærstu fyrirtækjum á Íslandi. Bifröst: Háskólinn á Bifröst.

Robbins, S. T. (2003). Organizational behavior. Upper Saddle River: Prentice Hall.

Schultz, T. (1961). Investment in human capital. American Economic Review, 51 (1), 1-17.

Taylor, F. W. (1997). Scientific management. Í Pugh, D. S. (ritstj.) Organization theory: selected readings. London: Penguin Books.

Zárraga, C. og Bonache, J. (2003). Assessing the team environment for knowledge sharing: an empirical analysis. International Journal of Human Resource Management, 14 (7), 12271245 . 